\title{
Gaps, Or the Dialectics of Inter-imperial Art: The Case of the Belgrade Surrealist Circle
}

\section{Sanja Bahun}

\section{Preamble: The Gap that is the Text}

Reflecting on 1920s Belgrade in her book Peeps at Many Lands: Yugoslavia, travel writer Lena Jovičić describes the paradoxes of urban cohabitation in a Balkan capital: tall buildings and small, dilapidated houses, creaking ox-carts and luxurious limousines, peasants in sandals and ladies in smart clothes, all coexist in this place where "East meets West in a curious jumble" (Yovitchitch 11). Jovičić detects "opposing forces everywhere: in the streets, in the houses, in the lives of the people" and surmises that, "in view of such extremes and contrasts you cannot but feel that there is a gap somewhere. The connecting link between one and the other is missing and so you constantly find that you suddenly drop into the gap."Jovičic, a Scottish-Serbian writing in English, may well have felt this gap particularly poignantly. But Jovičic is careful not to reduce the matter to Orientalization or autobiography: while the gap in question might be read as a property of either the observer or the depicted geocultural terrain, in fact it 
is constituted only in their interaction. The gap is geocognitive and affect-ridden, and its effects are both discomforting and productive, suggesting that disorientation is vital to the creation of places. Challenging the habituated perceptual-ideological parameters of space, the gap between the ox-cart and the limousine into which we stumble co-constructs the site we are traversing. Had this book, published in London in 1928, not been intended for British children's geography curriculum, one could have argued that Jovičić describes the geopolitical space in question as an inter-imperially informed surrealist.

This article zooms in on the gap identified by Jovičić and reflects on the challenges posed to literary studies by such cases of interpositionality: their repercussions on our understanding of lived temporalities, the strategies we use to translate this understanding into art and fiction, and the critical tools we deploy to evaluate artworks produced in this way. To assist in these ruminations, I deploy and further examine the concept of inter-imperiality and tackle the phenomena of "placedness" (Doyle and Winkiel 1), translatability, and the futurity of artwork. My guides are the multiethnic history of the Belgrade district called Dorćol and four surrealist artworks: the Yugoslav surrealists' 1932 piece of engagement art Facing a Wall: A Simulation of the Paranoiac Delirium of Interpretation. Survey (Pred jednim zidom: Simulacija paranojačkog delirijuma interpretacije. Anketa); two 1935 photographs by Vane Bor; and Marko Ristić's 1928 anti-novel Without Measure (Bez mere).

\section{Contexts and Mandates}

Lovers of synchronicity often hurry to pronounce 1922 the annus mirabilis of modernism. Provisional and problematic, this claim becomes reenergized if we remember the imperial dynamics of that year. It was the year when Mahatma Gandhi was sentenced to prison and a Bauhaus exhibition in Calcutta changed the nature of Indian modern art; the Irish Free State was born; the Fascists took over in Italy; the British unilaterally granted independence to Egypt and Tutankhamen's tomb was discovered; and the Turkish army defeated the Greeks in Asia Minor, resulting in an exchange of population that saw the displacement and resettlement of about one million Greek Orthodox Christians and about half a million Muslims. It was the last gasp of the Ottoman Empire, though. On 1 November 1922, the newly founded parliament of Turkey abolished the Sultanate, thus ending 623 years of monarchy and starting a radical reshuffling of state and culture. By this point, the long history of contestations 
and exchanges between Western Europe and the Timurid, Mughal, and Ottoman empires had already inscribed this mesoregion with specific imaginings, as witnessed in the 1922 German film Nosferatu: A Symphony of Horror (Nosferatu, eine Symphonie des Grauens, directed by Friedrich Wilhelm Murnau). Both the film and its (uncredited) literary inspiration, Bram Stoker's Dracula, channel the anxiety of external threat through the regional mythic figure of the vampire, modeled on the medieval Voivode of Wallachia Vlad Drăculea (Vlad Ţepeş). In the case of Murnau's film, however, the details of the character's fate seem to have been sourced primarily from the reminiscences of a displaced Serbian peasant, who, in 1916, had told a story about his "vampire-father" to soldier-turned-film-producer Albin Grau (Grau 6 ). The farmer was a member of the Serbian ethnic minority lodged in Romania after the establishment of the Kingdom of Serbia, and both his name and his fate remain unknown. He may well have moved to Yugoslavia, a state that, after centuries of colonial rule over its diverse populace, came into being in the aftermath of World War I and was ratified at the Conference of Ambassadors in Paris in 1922. Yet he is unlikely to have seen the film or to have read another text to whose production he unwittingly contributed: namely, Serbian-Jewish writer Monny de Boully's graphic novel Vampire, which was first published in Testimonies, the little journal of the Belgrade Surrealists Circle, and later republished in the Paris-based La Révolution surréaliste in 1925.

My tracking shot to Yugoslav surrealism reveals the Balkans as a strategic inter-imperial zone shaped by multilateral circulations. ${ }^{1}$ In my interpretation of Doyle's argument, inter-imperiality refers both to the experience of being positioned at the intersection of empires or, more generally, conditioned by simultaneous and consecutive imperial claims, and to the structure of relations and affects resulting from global inter-imperial interactions over time. This affective structure creates geocognitive deposits that shape and reshape agents of history at all levels. Whereas inter-imperiality is a wide world-structure-almost no region on Earth has been immune to inter-imperial contests, collusions, and their bottom-up contestations-the Balkans seems to have exteriorized this dynamic in a particularly vivid form. Vied over for its geographic position and its material and human resources for centuries - and politically and cognitively located at the intersection of the dying Austro-Hungarian and Ottoman empires, as well as between the demands of an imported notion of nation-state and indigenous styles of political action-the early-twentieth-century Balkans was a charged locus of colonial contests and cultural interpellations. The history of interacting empires and human motions 
between and against those empires created intense (if at times constructed) awareness of the region's interpositionality and fortified its operation as a "historical legacy" (Todorova 59). The latter shaped the investments and maneuvers of regional anti-colonial struggles, conceptualizations of history, and artistic expressions. To examine artworks in this context, Doyle argues, one needs to attend to "the contemporary dialectics of multiple empires" (680), "the interaction of these inter-imperial dialectics with anticolonial and other dissenting movements," and "the legacies of centuries of inter-imperial cultural accretion that inflect later literature." When approaching a text through this inter-imperial lens, scholars should work at once horizontally and vertically, scrutinizing both the textual traces of transformative interactions of multiple empires in the past and the gravitational waves created by contemporary imperial contests and contestations. It is in this way that an unnamed peasant meets an Expressionist filmmaker and a surrealist writer to situate this essay.

But why this particular constellation? Whereas the category of inter-imperiality offers fruitful ways to consider works of all epochs, it appears to be particularly serviceable for the consideration of planetary modernisms. Working in the context of escalating conflicts and the rapid development of planetary communication, travel, and trade, Doyle intimates, "geomodernists" intensely felt and self-consciously reflected on their inter-imperially sedimented positionality (685). Modernist artists' maneuvers at the rubbing edge of empires are particularly illuminating, I would add. The investigation in such liminal zones is heuristically useful for at least three reasons. First, and generally: the conditions that become easily discernible if we refocus our lens on the loci where the uncanny proximities of empires are directly negotiated reflect the universal operation of inter-imperiality, and are therefore useful for our reading of cultural artifacts produced at any site of imperial transaction. Second, and conveniently: the traces of inter-imperiality appear in the texture of artworks in particularly pronounced ways in those sites and at those times when the ripples of imperial contests and interactions are most intensely felt, either due to recent historical fissures or as a consequence of the failure to narrativize historical cross-breeding into the originary fantasy and retrospective finality of the nation-state. Third, and programmatically: the artworks and art practices that have emerged in communities exposed to the violent interactions of empires and material suffering for a long period tend to be less known globally, precisely as a result of this history of interruptions and often rigid social, economic, linguistic, and access-to-education 
hierarchies between and within empires. They are vulnerable and prone to obliteration in the global economy of modernist artifacts. Their emphatic "placedness," along with the tensions occurring between vernacularizing practices and cosmopolitan movements like surrealism, make the modernist artworks created in such areas not only poorly visible but also partly untranslatable to a global audience. Because their products fall in between the models of comprehension and patterns of interpretation we have developed, and because our insistence on the irreducibility of indigenous modernist practices to external descriptions has mostly failed to generate alternative homegrown approaches, the modernist practices inter imperia tend to be misinterpreted or neglected. The aesthetic production of the Belgrade Surrealist Circle, operational in the liminal (and, history would prove, transient) zone of Yugoslavia, belongs to this category.

Founded in 1918, amid the postwar inter-imperial shuffling of power, Yugoslavia—initially named the Kingdom of Serbs, Croats, and Slovenes-constituted the first union of predominantly South Slavic communities previously living in the territories of the Ottoman and Austro-Hungarian empires. For the majority of its history, the region has served as a borderline between empires, and its population has often been viewed (and it has viewed itself) as a wall between the West and the East, a perception rooted in the inhabitants' experience of serving as forcefully conscripted frontier troops. These border communities gained independence in a series of events commencing with the mid-nineteenth-century liberation wars, the 1877-78 Russo-Turkish War, and the 1878 Congress of Berlin. Consistent with the longue durée history of the region as the site of contests and coformation, the very foundation of Yugoslavia was contingent on an inter-imperial incident with global repercussions: on 28 June 1914, Gavrilo Princip-an impressionable youth whose father had participated in the 1875-77 Herzegovina Uprising against the Ottomans and had transported illegal migrants across the border between the empires-assassinated Austro-Hungarian Archduke Franz Ferdinand at Latin Bridge in Sarajevo. The event sparked the First World War but also enabled the unification of the South Slavs. The union operated as a constitutional monarchy from 1918 to 1929, an absolute monarchy and dictatorship from 1929 to 1934, and a parliamentary monarchy, one increasingly dependent on Nazi Germany, from 1934 to 1943. The Turks, French, Germans, Russians, Italians, and British continued to battle for cultural hegemony in the region, with the French interpellation particularly palpable in education, as instanced in the schooling of about 3,500 Serbian children, including many 
future surrealists, in France during World War I. Caught between the desire for independence and the legacy of imperial claims, and between modernizing aspirations and a conservative political set-up, the new Kingdom of Yugoslavia was a highly repressive state with a notorious impressment law and penitentiary system for the dissenting. Unsurprisingly, then, since the very beginning of the Yugoslav monarchy, the ground was also receptive to the transfer of USSR revolutionary knowledge, spread among the members of undercover resistance organizations. These counted in their ranks many affiliates of the Belgrade Surrealist Circle.

\section{Walls, Roads, People: The Belgrade Surrealists' Engagement Art}

Coincidentally, in the year of modernist miracles, 1922, young Marko Ristic, later the leader of the Yugoslav surrealists, published his first poetry, started international correspondence, and took up the editorship of Ways, a Belgrade-based little magazine dedicated to contemporary literature. Over the following year, Ristic would transform the journal into a voice of international proto-surrealist literature and art, and facilitate the coming together of a like-minded circle. Over the three periods of the Belgrade Surrealist Circle's existence-those of the group's individual and joint art practices (1922-29), its operation as a public organization (1929-33), and its post-detention/dissipation activities (1933-40) — the surrealists published more than twenty books of poetry and prose, as well as a few manifestos, theoretical treatises, magazines, and bilingual journals; produced a range of public interventions; and mounted one group presentation/exhibition. ${ }^{2}$ The members of the circle were mostly highly educated, merchant-class youth, many of them of Jewish or Aromanian (Tsintsar) descent, and most of them living at the time in or near the Belgrade neighborhood of Dorćol. Beginning in early 1924, the Belgrade and the French surrealists collaborated intensely and enthusiastically. But the two circles also harbored profound differences, stemming from the divergent "placedness" of their work: that is, the site-specific convergences between material history and intellectual history and the meanings that art production acquires in each context. ${ }^{3}$ The Yugoslav state authorities perceived the Belgrade Surrealist Circle as a dangerous political party rather than an artistic group. Its members were occasionally imprisoned and many of their publications were banned, while the arrest and detention without trial of several key members in December 1932 put an end to their public activities. Accused of excessive appropriation of both 
Western art and Soviet politics by the local cultural elite, the Circle nevertheless produced artwork that activates regional ethnography and emphasizes the social responsibility of the artist. Actively committed to a proletarian revolution, the Belgrade surrealists understood their artistic enterprise as a subversive act-"boundless, unselfish, and moral" (Ristic, Oko 166) - by comparison to which the French surrealist activities, even at their most radical, were unhelpfully innocuous.

It was both within this contemporary context and with the deep-time inter-imperial legacy in mind that the collective produced some of its most memorable work. One such is a piece of conceptual engagement art called Facing a Wall: A Simulation of the Paranoiac Delirium of Interpretation. Survey. The collective commissioned (or acquired) a photograph of a dilapidated city wall taken by Rahamim Raka Ruben, a photographer at the newspaper Politika, and then asked six members to visually interpret the picture. Their artistic responses to Ruben's frontal view close-up took the form of various interventions, which were subsequently photographed, processually arranged around the original photo, reproduced on two pages in the third issue of the surrealist journal Nadrealizam danas $i$ ovde (Surrealism Today and Here), and accompanied by Ristićs article "Pred jednim zidom-objašnjenje istoimene strane ilustracija" ("Facing a Wall-An Explanation of the Eponymous Illustration Page"). ${ }^{4}$ This collective action had four stages: the photographing of the wall, free-association, intervention (what they called "materialization of the idea"), and reflection (the published article) (Ristic, "Pred jednim zidom" 51). Paranoiac simulation had already been expounded on in both Salvador Dalí's "The Stinking Ass" ("L'âne pourri," 1930) and André Breton and Paul Éluard's The Immaculate Conception (L'Immaculée conception, 1930), but the immediate context for this collective action artwork is the philosophical treatise Outline for a Phenomenology of the Irrational (Nacrt za jednu fenomenologiju iracionalnog, 1931), written by Ristić and Koča Popović. As this book clarifies, simulation is a volitional, scientific action aimed at awakening the latent content through an external, conscious impetus. This process produces a simulacrum that, rather than being a result of solitary simulation, emerges only through the twin hermeneutic (paranoiac) activity of the producer of the work of art and its interpreter. Risti and Popović insist that such simulacra are also markedly historical: they articulate the dialectical struggle between the thought and the unthought or not-yet-thought. ${ }^{5}$ This struggle, felt acutely by the Belgrade surrealists, governs and shapes the historical subject-in-becoming. 

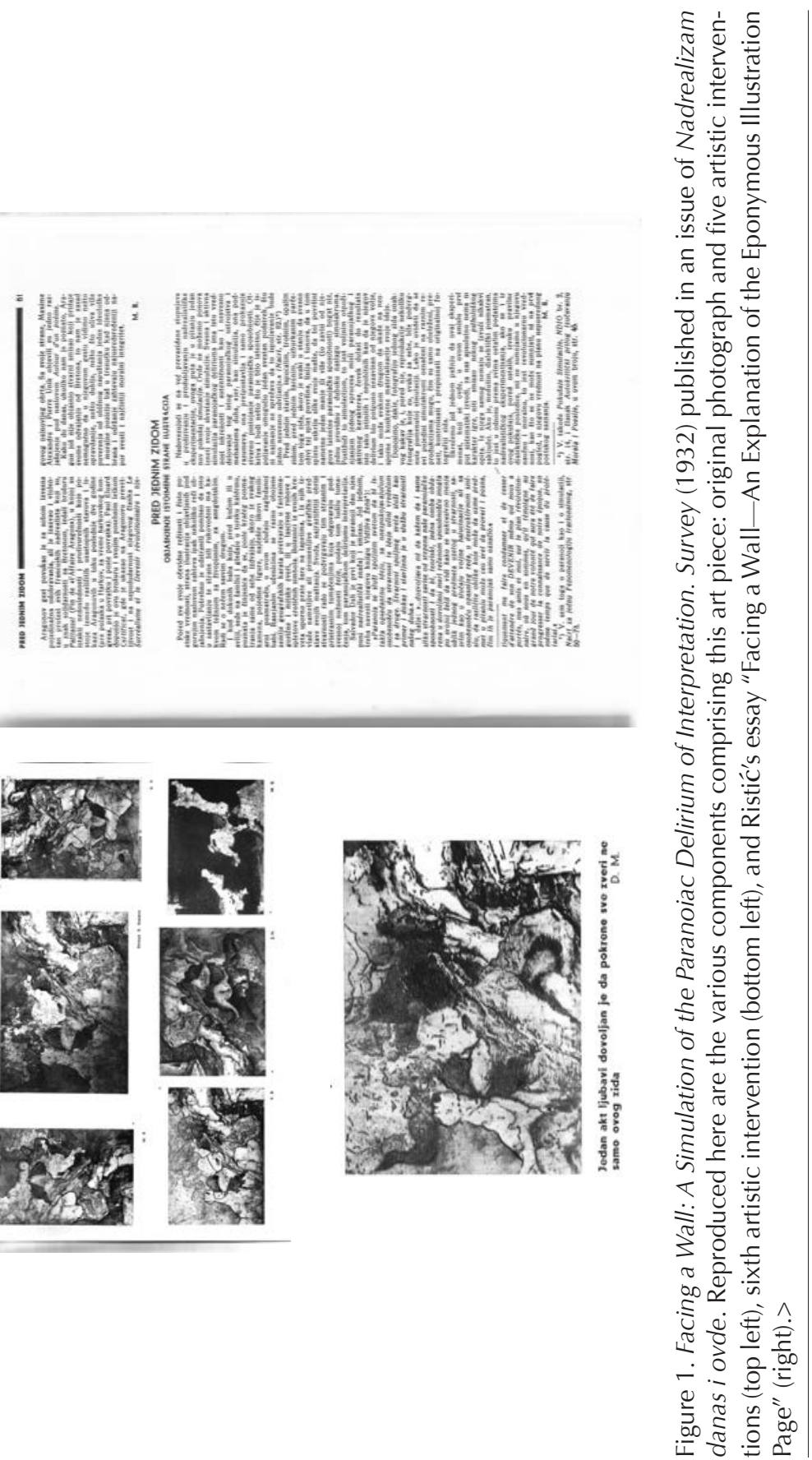
So where does this phenomenological continuum (from the observable to the unobservable and back into an observable history of becoming) leave us, in terms of the installation Facing a Wall? What Ristić does not mention in his article, but what I am particularly struck by, is a pre-phase of the project: the very choice of (the picture of) the wall and the insistence on the materiality of an infrastructural object that, while taken out of its physical setting of 1932 Belgrade, nevertheless confirms it. My hypothesis is that self-consciously interimperial artworks like Facing a Wall negotiate their "placedness" in specifically marked ways. Positioned uncomfortably in relation to and between different imperial narratives, the authors and works that bear witness to the violent histories of empires often resort to emphatic referencing of site-specificity: they insist on material substances and their conative and affective impact. Understood in this way, Facing $a$ Wall instates a bidirectional dynamic. As much as the exterior impetus does not deprive the artifact of the quality of being an articulation of the unconscious flow (and thus also a participant in international surrealist conversations), so the intention to elicit the interior affective content that binds objects and observing subjects does not remove from the artifact the quality of being a representation/simulation of a particular physical infrastructure in 1930s Belgrade, metonymically linked to the deep and contemporary history of the area.

The reason for this orientation toward site-specificity lies in the geocognitive liminality of the terrain out of which the work sprouted. For centuries, those who called Belgrade their home have been intensely aware of its status as an inter-imperial cauldron, a "borderline workshop" in and through which empires and states were formed (O'Dawd 172). Favorably situated at the low hills surrounding the confluence of the Sava and the Danube, the settlement has attracted more than forty waves of invasion, formation, and transformation by the Celts, Romans, Huns, Byzantines, Ottomans, Habsburgs, and the Slavs themselves. One of the most charged imperial frontier points ran through the Belgrade neighborhood of Dorćol, precisely where Kalemegdan Fortress stands and where the wall introduced in Facing $a$ Wall in all likelihood stood; photographer Ruben lived and had a studio in the neighborhood at the time. Dorcol has long been the axial point of the region's inter-imperial dynamics, and the city's main fortification-a Roman castrum, then the Turkish fortress of Kalemegdan-its walls delimiting the neighborhood and facing another fortification wall on the other side of the Danube, stands as an emblem to this history. The area was traditionally organized by the crossroads of today's streets of Dubrovačka, Kralja Petra, and Cara Dušana. In the 
Middle Ages, this crossroads hosted four major trade routes leading to Vienna, Widdin, Istanbul, and Dubrovnik, respectively; Dorćol, "dört yol," means "four roads" or "crossroads" in Turkish. Fronting the border between empires, Dorćol was for centuries a terra incognita, a hub for refugees, homeless, and tradespeople. Located on a marker of division, the neighborhood also positioned itself as defying the border, insouciantly stretching across the walls, and, through all the legitimate and illicit commerce of goods and people that took place there, blurring the physical and cultural boundaries between the imperial zones. The Belgrade Surrealist Circle's site-specific art obsessively engaged the physical and ideational manifestations of boundary walls: the Belgrade surrealists described and pictured walls, meditated on the metaphorical nature of walls, and used images of Belgrade walls to trigger art-making, as in the case of Facing a Wall. Their choice to focalize the simulation through the fragment of a Belgrade wall-a fractal of a larger whole (a wall) that in itself is a fractal of a yet larger whole (a house, a city) —was thus fitting, in that the photographed wall could serve simultaneously as a metaphorical trope and as a metonymy of both deep and contemporary history. As a zero-point of simulation, the close-up of the wall could also attract and contain two opposing functions that the Circle ascribed to walls more generally: their permeability, or porosity, and their status as a palimpsest of histories and sociopolitical inscriptions in deep time, on the one hand; and their capacity to operate as prison walls, reflective of an incompetent and repressive state, on the other. ${ }^{6}$

In the early twentieth century, Dorćol was an eclectic architectural composite hosting the traces of imperial contests and those who lived them: the morsels of the oral history of Serbs, Turks, Jews, Armenians, Aromanians, Roma, Greeks, and Germans. Within a square mile one could find a synagogue, a mosque, an Orthodox Christian church, and a Catholic church, a fact marveled over by Jovičic, among others. ${ }^{7}$ The area had already been divided informally along class and architecture lines into the less affluent Lower Dorćol and the baroquely revamped Upper Dorcol in the nineteenth century, and it underwent further significant changes in the first decades of the twentieth century. Two urban structures that opened in 1932 emblematize these developments: the Ilija M. Kolarac Endowment, a state-sanctioned cultural center in the capital, on the upper edge of Dorćol, and the coal-fired power plant named "Power and Light" in the Lower Dorćol quay. The latter's symbolic name and impressive crane arching the river aimed to invoke in the city dwellers a sense that they were ushering in a new age that would transform the 
cluttered lower Dorćol into a gridded industrial zone. In terms of its location and ideological ambition, the power plant presented itself as an ungainly continuation of the Kalemegdan Fortress.

The Belgrade surrealists could read the sediments of interimperial frictions perhaps primarily in such instances of the unique lack of architectural consistency in the Belgrade cityscape. The latter led young Swiss Charles-Édouard Jeanneret-later known as Le Corbusier-to describe Belgrade in 1911 as an "uncertain city" and "a ridiculous capital, worse even: a dishonest city, dirty and disorganized" (43). ${ }^{8}$ Le Corbusier's pairing of the category of honesty with organized urbanity and planned certitude not only announces his later theory of purism but also discloses its affiliations with a more general imperial vision of interstice regions as supposedly messy, impure, visually and cognitively unclear, and thus both ontologically and ethically suspicious. Surveying the city from the vantage point of Kalemegdan, Le Corbusier must have felt both perplexed and threatened by all this messiness and misrule, indeed fearful he might fall into one of those gaps identified by Jovičić. He seems to have been profoundly disinterested in, even anxious about, the potential of this unreadable cityscape to harbor what, in an opposite argumentation about the legibility of cities, Michel de Certeau would call the liberating "practices of everyday life" (91). Dwelling on these gaps in urban legibility, however, one is led to another artifact of the Belgrade Surrealist Circle, which exploits precisely the sense of uneasiness that the lack of visual and cognitive clarity imparts: Vane Bor's (Stevan Živadinović) 1935 series of photographs of a semideserted Dorćol underpass, Milica S. Lazović as a Shadow, or Two Minutes Before Crime (Milica S. Lazovíc kao senka ili dva minuta pre zločina) and One Minute Before Murder (Jedan minut pre ubistva).

Capturing the perspective of someone looking down at a woman (fig. 2) and at a woman and a man (fig. 3) in the white roadway below, this series of photographs was probably taken during a random walk but was carefully staged as a pair of film frames showing the cobblestone road on both sides of a bridge. The road is demarcated on both sides by tall cement walls, constituting two main compositional lines that converge toward the horizon of each image. Exemplary of the artistic practice that Pavle Levi recently called "cinema by other means" (xiii), Bor's stop-motion photograph series foregrounds the interplay of geometrical lines and shapes, darkness and light, similar to the aesthetic of Expressionist films like Nosferatu..$^{9}$ The titular crime is oddly absent in Bor's photographs, but it looms in the surprising emptiness of urban space, reminding one of Eugene Atget's photo- 


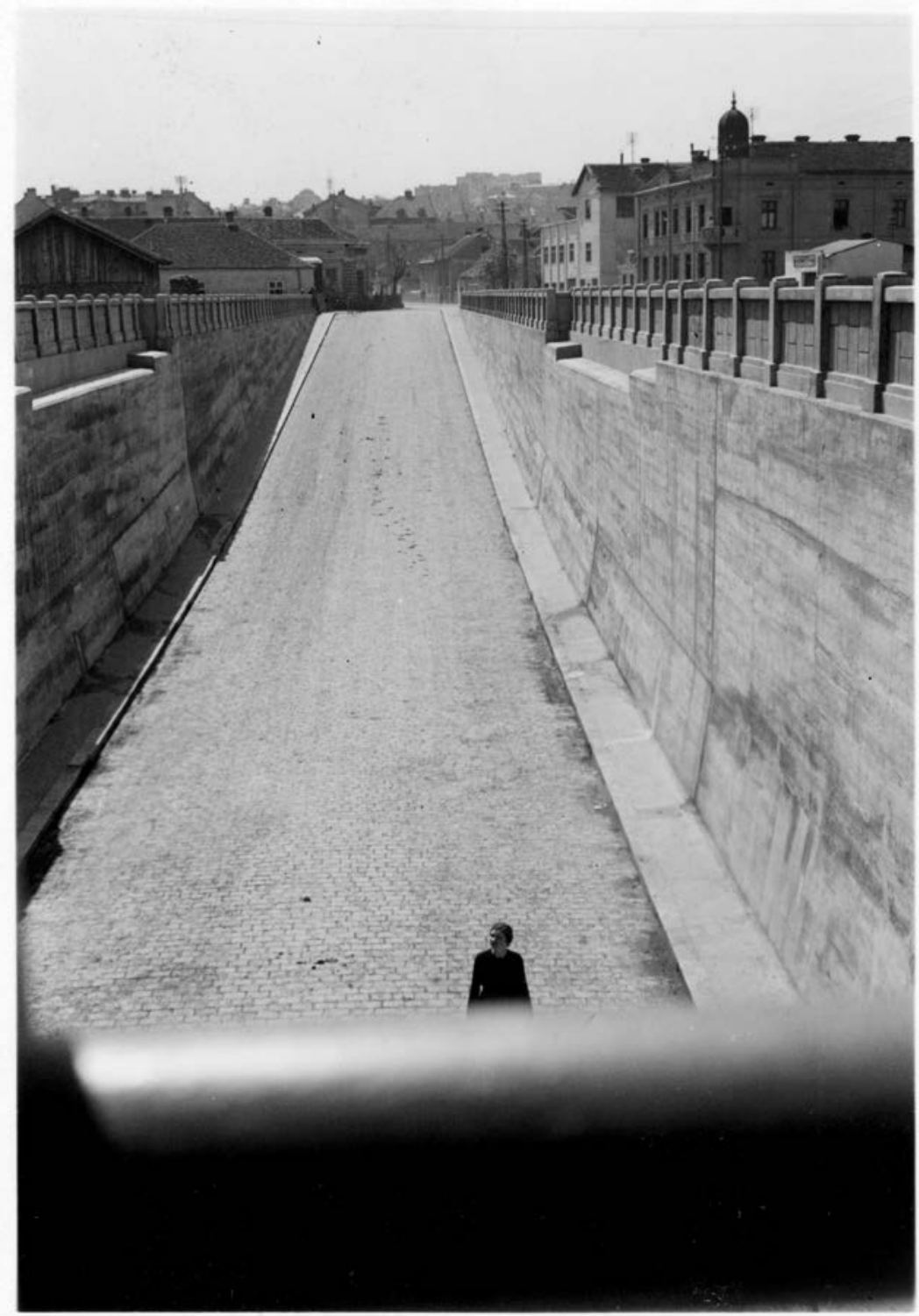

Figure 2. Vane Bor (Stevan Živadinovi'c), Milica S. Lazović as a Shadow, or Two Minutes Before Crime, 1935, vintage photograph, 90x60mm, Inv. No. M112. Courtesy of the Museum of Contemporary Art, Belgrade.> 


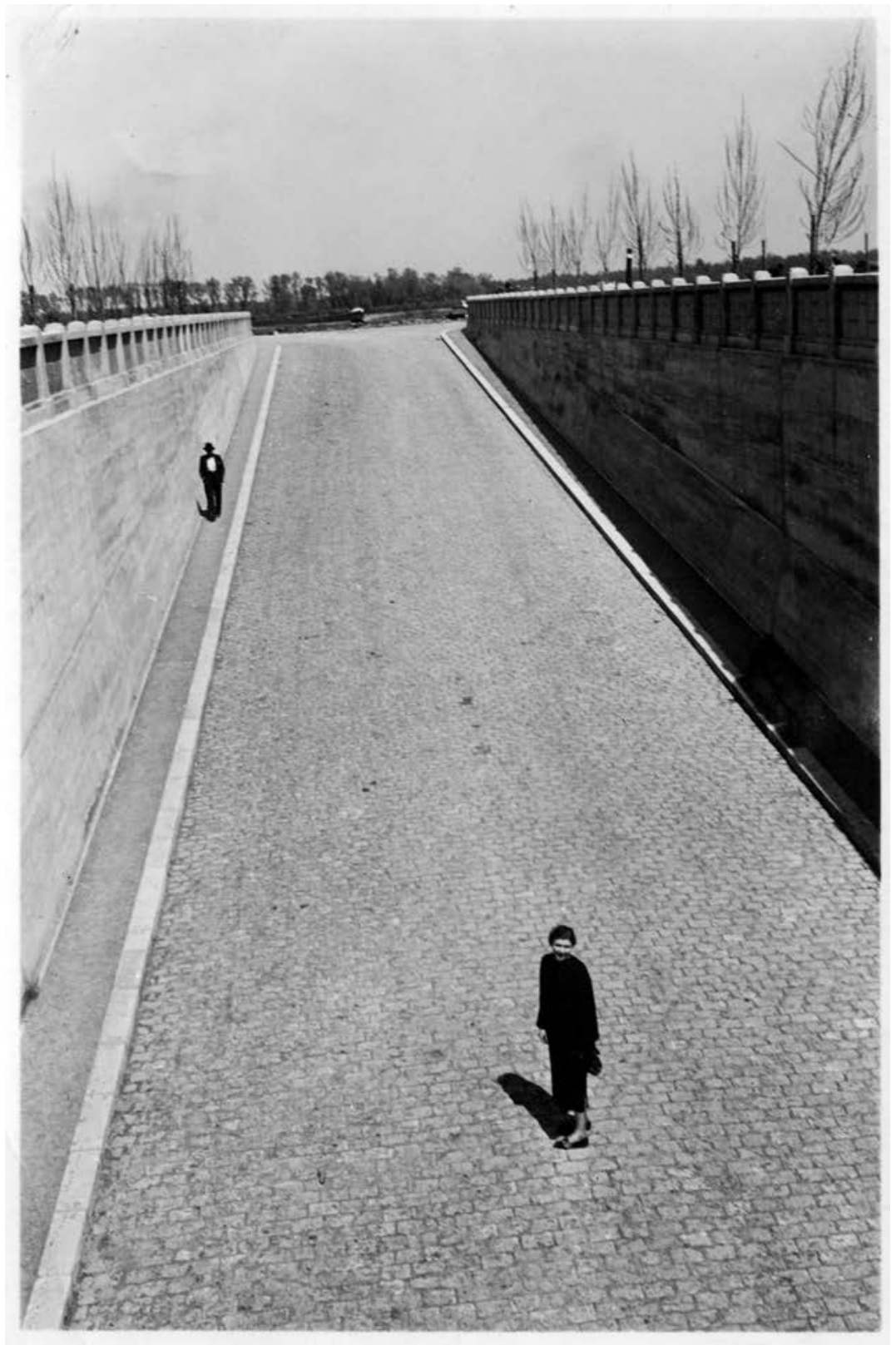

Figure 3. Vane Bor (Stevan Živadinovi'c), One Minute Before Murder, 1935, vintage photograph, $87 \times 62 \mathrm{~mm}$, Inv. No. M111. Courtesy of the Museum of Contemporary Art, Belgrade.> 
graphs of deserted Parisian streets, which Camille Recht and Walter Benjamin memorably linked to the scenes of crime. ${ }^{10}$ For my purposes in this essay, however, I identify the orientation toward interaction with the viewer as the key aspect of Bor's series. In Milica S. Lazovic as a Shadow, the slanted occlusion that tantalizingly diminishes the view draws the viewer into an uncomfortable hermeneutic effort: the blurred bordure signals the mythic operation of the bridge as passage to death, but the uncanny close-up also suggests that the viewer is somehow implicated in this passage or in the crime itself. On her way to the river (of death?) in One Minute Before Murder, then, the woman has suddenly turned back; she looks away with a half-smile, as if interacting with someone under or on the other side of the bridge, while a passerby approaches her, hands in his pockets, unnoticed yet. The cinematicity of Bor's series forces the viewer to become both editor and cocreator of this film: to supplant a montage between the two film frames and, importantly, create a dénouement. All of this places the observer in the position of not only a witness to a crime but also, hypothetically, its perpetrator.

The Belgrade surrealists' interest in the time before and after crime was directly historical. While mythic in tenor, Vane Bor's photographs disclose, just as Benjamin demanded, "every inch of the city as the scene of crime" and "every passer-by as a culprit" (256). The 1935 artwork indexes some specific crime-related events in the region's recent history: the discovery of 53 skeletons of World War I soldiers near the photographed site, the ratification of a trade treaty between Yugoslavia and Hitler's Germany, and the assassination of King Alexander of Yugoslavia-all of which occurred in 1934, less than a year before Bor's photographs were taken. ${ }^{11}$ Bor may have also had in mind some deep-time, inter-imperial dynamics related to the site his photographs memorialize. The location captured in Bor's photographs overlooks, on the one side, Dubrovačka Street (in Milica S. Lazovic), and, on the other, the Danube riverbank (in One Minute Before Murder); it sits proximate to the trade crossroads out of which the neighborhood of Dorćol itself had developed..$^{12}$ The cobblestone road captured in Bor's photographs was located-and the wall used in Facing a Wall may have been located-in the immediate vicinity of the Jewish quartier, a small commerce area of Dorćol that had become a refuge for the Ladino-speaking Sephardic Jews fleeing Spain and Portugal in the fifteenth-sixteenth century and the Ashkenazi Jews from Central Europe thereafter. The area had prospered as a result of its inhabitants' important role in the salt trade between the northern and southern Ottoman provinces. The two horizons in Bor's 
photographs, furthermore, embody the contrasts that characterized 1930s Belgrade, themselves legacies of inter-imperial history. In the Dubrovačka street-facing photograph, the horizon is a dense mixture of heterogeneous abodes: ground-level Turkish-style houses, two-floor baroque edifices, and, toward Upper Dorćol, modern buildings. In the Danube-facing photograph the horizon is ominously consumed by the unpopulated riverbank, a recently constructed canal that allowed cargo ships to bring coal for the "Power and Light" plant. Importantly, in terms of the epistemological articulation of space, Bor's photographs foreground the claustrophobic enclosure of both horizon-paths between two tall, bare walls. Such is the architecture of public crime.

\section{Anti-Monuments and Anti-Novels}

As the previous discussion suggests, the state efforts to assert a national identity in 1920s and 1930s Yugoslavia were mostly played out in the streets of its capital. The most popular of the innumerable monuments dotting Belgrade streets in the early 1930s was a fountain called Čukur ̌̌sma (Čukur Fountain, or A Boy with Broken Jug; fig. 4), which opened to the public in Upper Dorćol in 1931, the year before the Facing a Wall project and four years before Bor's photographs. It commemorated a place where, in 1862, Turkish soldiers killed thirteenyear-old Serbian boy Sava Petkovic, an event that led to two uprisings of the indigenous population, the establishment of the Kingdom of Serbia, and, eventually, the unification of South Slavs itself.

The fountain, whose construction was financed by a Tsintsar tobacco merchant named Vanđel Toma, is a blend of sculptor Simeon Roksandić's anachronistic hyperrealism and state architect Jan Dubovy's functionalist-modernist corrective. The Belgrade surrealists bemoaned both its displaced nature in the surrounding architecture and its appropriation of real human suffering for blatant nation building. Their anger is illuminating. While Parisian surrealists celebrated the capacity of monumental art to deaden the past and thus liberate the present, the members of the Belgrade Circle detested historic monuments. Instead, they found scriptural-revolutionary potential in decrepit walls and streets almost deprived of any outward signs of historical specificity-except that it was precisely their dilapidated, unembellished, forcefully erased condition that testified to the workings of history. As both Facing a Wall and Bor's series intimate, the collective believed that historical occlusions could not be brought into historical presence through either abstraction or vocal 


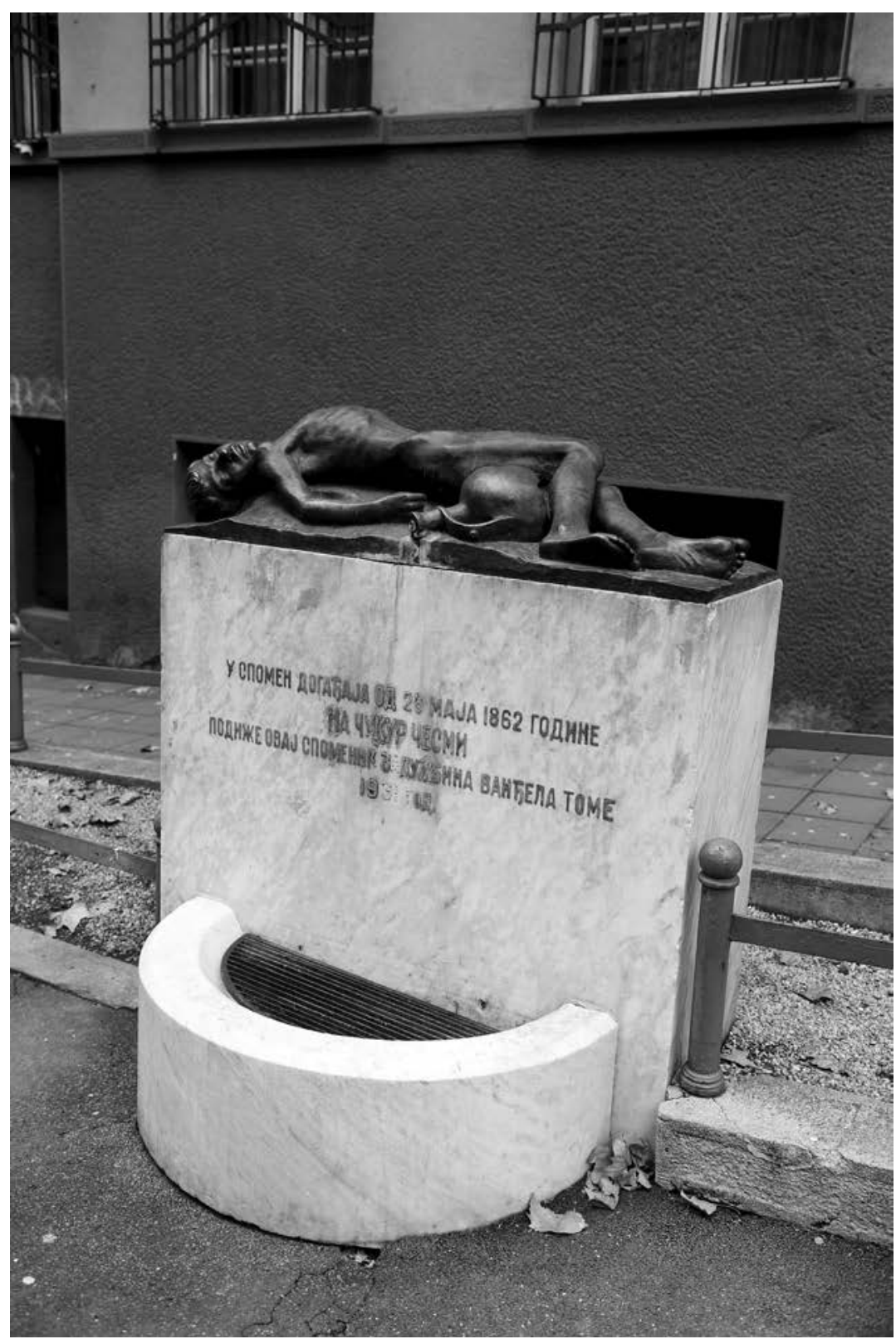

Figure 4. Čukur fountain, or A Boy with Broken Jug. Photograph: Aleksandar Dimitrijevi'c, 2017. Courtesy of Aleksandar Dimitrijević.> 
commemoration. Rather, their practice suggests we should deploy strategic selection and treat physical space as a mystic writing pad, where the traces of sedimented history would be elicited by methods of facilitated indirect association; for example, paranoiac simulation (Facing $a$ Wall) or interactive montage (Bor's photographs). ${ }^{13}$

How does one write an anti-monument, though? How does one preserve in it the poignant traces of imperialism-that "most facile form of dogmatism," as Ristic characterized it (Bez mere 233) —and make them active in forging future history? ${ }^{14}$ These questions tormented Ristić as he set out to compose his own anti-monument, the novel Without Measure. Ristic wrote the novel in Belgrade and Paris in 1927, during a period of intense study of Hegel and animated exchanges with Breton (the latter was writing Nadja at the time, and the two novels would be published nearly simultaneously in May 1928). ${ }^{15}$ Without Measure is an antithetical text. The book's status as a text that negates itself is explicitly confirmed on a number of occasions in the novel and most extensively in chapter 32, "The Foresigns of Chasm." In the metatextual diatribe that consumes the entire chapter, the reader learns that the text is a "novel without a novel" and, more pointedly, that "it is from the interiority of this book that its very negation erupts" (204). ${ }^{16}$ Without Measure is thus an anti-novel in the precise fashion in which the genre would manifest itself in the texts of Nouveau Roman and would be theorized by Jean-Paul Sartre some twenty years later: it reads like a detective novel but simultaneously undermines its own generic status. ${ }^{17}$ Insofar as it reads as a novel, however, the text is focalized through a quasi-autobiographical narrator who follows the wanderings of a man appositely named Roman, a word that means "novel" in both Serbo-Croatian and (imperial) French. The narrator and Roman stroll in and out of the narrative's diegetic reality, from history into mythic suprahistory and back into contemporary political and cultural debates. The opening pages suggest that the protagonist has migrated to the city center, a move that implies physical and metaphorical descending: "By that shaded side of the road Roman descends into the city, where a water-dragon and the most forceful reflection of the past are awaiting him" (33). This opening significantly reconfigures the cityscape as the space where the traces of the past are most acutely felt, if only one agrees to face them by way of an impossible creature (the water-dragon) and an impossible (both immeasurable and resistant to being measured) narrative mode, as announced in the novel's title. The novel thereafter follows the protagonist and the narrator as they interact with these traces and experience fascination, resentment, and radicalization. 
While the narrative tension rises and the murders, dream murders, and executions accrue, the two entities become progressively indistinguishable from one another until they finally coalesce into a writer penning a polemic response to a certain Ivan Nevistić.

Creating a writing pad for the sediments of private, cultural, and general history, this narrative meandering is oriented by what Ristic calls "geometrical points" (60): a mansard where the writing takes place (point 1), the site of dream that dreams itself dreaming and writing (point 2), and a place of execution by the firing squad (point 3). These general chronotopic points are further punctuated by subsidiary references to locations in Belgrade, Paris, Cannes, and Vrnjci, including an avlija (Turkish for "yard," a word widely adopted in local dialect during the Ottoman rule) at 79 Kralja Milana street, Belgrade, the real-life setting of Ristićs childhood and the projected locus of imagination play in the novel. This chronotope is continuously built and dispersed as readers enter and exit various characters' stories, each with its own imperial accretion. Of these tales, perhaps the most memorable is that of a melancholic Turk who has sailed in on a yacht from Tsarigrad ("City of the Caesar," present-day Istanbul), fleeing the spleen he once succumbed to when he sat on a bench listening to the hysterical voices of the enslaved women inside his harem. His escape to Belgrade (and arrival into Ristić's text) is in vain, for he is pursued by a "demon who fears neither Cross nor Crescent" (100), and the depiction of his wanderings is quickly intercepted by the image of a black ship carrying coal from Newcastle, one of those carriers seen around the "Power and Light" plant. The last tableau swiftly reconstellates the novel's chronotope into an industrial-capitalist dystopia: we learn that the ship is a "kin of this polluted air ... , this eclipsed sun, [and] this leaden sea that grinds itself into copper coins" (101). No sooner has this distinctive image been introduced than the text reverses into metatextuality, ending with the question of whether Roman - the protagonist as well as the genre-is actually the Turk's demon, or perhaps his cotraveler in obsession, the two devils wandering the seas together. Ristic's reworking of the Wandering Jew myth irreverently crosses cultures and sediments of reference to assemble an image of history as the melancholy story of displacement and exploitation, in turn commenting on the proclivity of the genre of the novel to voraciously feast on this history.

Writing itself is, of course, one of the main subjects of Without Measure, performatively explored with a determination reminiscent of one James Joyce. ${ }^{18}$ Ristićs's narrator continuously ponders the nature of fiction and probes the quality and integrity of his own writing. In- 
terspersed with accurate and inaccurate quotations and paraphrases that gloss everything from Lautréamont's and Rimbaud's poetry to children's books, regional folkloric sayings, and 1920s cinema, the book also aims to provide the reader with a short history of literature and a surrealist (re)writing guide. But the text engages in rewriting cultural history cautiously: while the narrator proclaims a surrealist disdain for the belle lettres - that is, the realist novel and its habituated modes of production and reception, as opposed to poetry-he also argues against l'art pour l'art escapism and both celebrates and questions the Gothic tradition. Metatextuality and intertextuality in Ristićs novel thus seem to serve a more comprehensive flexing of literature. Rather than simply challenging one mode of literary expression, Without Measure stages a dialogical interaction between various types of utterance, textual planes, and elements. ${ }^{19}$ The novel consists of not only the loose plot outlined above but also its own paratext and visuals, which have accrued across three editions (published in 1928, 1962, and 1986): the 1928 acknowledgments, motto, footnotes, and kabalistic pictographs; the 1962 author's prologue, endnotes and reproduction of Max Ernst's Owl (A Bird in a Cage) (owned by Ristić since 1927); the 1986 reproduction of Giorgio de Chirico's 1914 Piazza d'Italia, and others. These diegetic and paratactic materials further interact with the elements of fairy tale, detective chronicle, Gothic novel, manifesto, satire, and symbolist performance. Ristić's expression is dominated by convoluted sentences that take advantage of the property of Serbo-Croatian as a case-based language to delay the appearance of the subject, or even omit the subject altogether. This choice simultaneously unsettles and heterogenizes the narrative chronotope and foregrounds the nature of the text as an unending identity quest. The last impression is reinforced by the frequent use of relative clauses and meandering parataxis, a performative stratagem that (as suggested by a fleeting intertextual reference and the holdings of Ristićs personal library) presents a covert dialogue with Marcel Proust. The interaction of narrative planes, modes, and references in Ristićs anti-novel thus dialogizes the genre from within; but it also performs a specific historical mandate.

This mandate is visible at the ultimately dialogic plane of the novel, that of the relationship between figurative bodies. Ristićs Without Measure might appear to be a prototypical surrealist novel: the spatiotemporal coordinates of the protagonist's and narrator's actions are blurred (or, as the title suggests, without ascertainable measure); the relationship between subject, narrator-object, and protagonist is indeterminable; and the text traverses the zones of 
dreams and reality. In tune with the status of the text as a writing pad, however, the protagonist and the narrator remain metatextual traces rather than iconographically embodied beings. Roman/roman simultaneously operates as the subject of the work of art, the activity of its production, the artwork itself, and the artwork's formal, generic, and contextual interpretation. Likewise, the quasi-autobiographical narrator is involved in the story as both observer and participant, but he is also metatextually distanced, more comparable to the later development of the role of the narrator in Nouveau Roman than to the typical narrating entity in a surrealist novel. The choice of the male pair of protagonists (rather than the male-female combination found in, for example, Breton's Nadja) assists the politics of Ristić's text: it helps him contain at the periphery of the text the surrealist fascination with the female muse and to foreground, instead, the narrative line of maladjustment and revolt. The latter strand, in turn, reconstellates the scope of meanings one may attach to the female figures-fictional, autobiographical, and intertextual-in Without Measure. Operating from the charged margins, and often ambivalently glossed by the pronoun "ona" ("she"), they present metaphorical articulations of freedom (sloboda, a female noun in Serbo-Croatian) or metonymic signals of a will to freedom, as in the chapter-long discussion of Wanda von Sacher-Masoch's 1906 memoirs and in the dream commentary on gender relations in the USSR. As the writer keenly reinterpreted his own text in the prologue, both the form of the text and the desires it articulates are continuous with the struggle for freedom - that is, political freedom.

Surrealist art tends to be oriented by a notion of freedom that is overarching yet often abstract, but Ristićs target is specific and direct. While writing Without Measure in Paris, he complained to his friends in Belgrade about a sudden lapse in communication between the two surrealist circles. On 15 February 1927, Belgrade surrealist Milan Dedinac replied: "Marko, I cannot advise you to pass over certain differences. ... Our position is immeasurably more stupid and more brutal than theirs in France. ... Just think what freedom means in our country ... and what in theirs (not to mention our press law!)." Informed by a longue durée history of invasion and occupation, the concept of freedom is herein geocognitively re-sited to articulate the legacy and condition of inter-imperial contestation. This is why, in Ristićs novel, the search for unconditional freedom and freedom relevant to one's integrity-one that would be universal yet "immanent to ... our existence" (233) — segues seamlessly into a dialectical challenge to the very notion of freedom as enshrined in 
the philosophical discourse and onward into the pursuit of political freedom: a revolution in Yugoslavia. While the ethical imperative of resistance should not be regarded as normative to the operation of subaltern inter-imperial positionality, it operated vigorously in the Belgrade Surrealist Circle. In Without Measure, these questions are addressed through the play of metaphoric substitution and the metonymic extension of leitmotifs such as the revolver and atentat (assassination) —wherein the atentat of "a certain artistic convention" (233) becomes, across three editions, inextricably linked to the past, present, and future history of the region (for example, assassinations of Franz Ferdinand, five Croatian MPs in the Parliament in 1928, and King Alexander in 1934). In the face of an abstract and/or mediated notion of freedom, the narrator of Ristićs text muses, the only "position which remains fruitful for the spirit [is] a MORAL and REAL attitude: a working, active rejection of a certain order which has proven itself as dead and artificially maintained" (233) in the form of "a bloody dialectic" (234). For, "passive resistance is insufficient."

For the Belgrade Surrealist Circle, yearning for freedom is, however, intensified by another kind of captivity, an incarceration in regional and global imperial inscriptions that, parenthetically, the French group might have also unwittingly deployed. These are meticulously related in Without Measure: "East, West, Catholicism, Mediterranean Culture, Europe in Danger, Balkan Man, Racial Expression, the Slavic Mission, Reslavicisation, what are all those games and toys to me," queries Ristić's narrator, "and what is love for homeland, nurturing beauty, belief in good, and other abstractions?" (233). Some of these labels are space- and time-specific and gesture toward particular routes of inter-imperial interaction in the early twentieth century; others are recognizable as more permanent discursive currencies, deployed and handled without question even today. As an impassioned and lengthy footnote to the text further explicates, it is the concept and discourse of "racial art," whose rise and global spread we can date to the late 1920s, that bothers Ristic most (233). He deems it a doubly limited, superficial way to refer to identity through entity, entrapping us, sometimes unawares, in an imperial construction. And "imperialism itself, including imperialism of the spirit," the footnote-voice argues, is "the most facile form of dogmatism" (233). The footnote folds together the phenomena of overseas and continental imperialisms; it suggests a continuity between the discursive ambivalence of the terms "racial art" and "racial expression"-which were used widely in the American and French periodicals that Ristic read in 1926 and 1927-and the concept of 
"imperialism of the spirit," often deployed to justify reinvigorated Germanic nationalism in multiethnic Austria and the former Habsburg colonies in the 1920s. ${ }^{20}$ The polylateral bridges Ristic thereby forges are illuminating: they cohere an image of an inter-imperially intersected world, where the strategies of imposition and suppression are ultimately comparable.

How, in this context, does one preserves the "integrity of one's freedom" (233) and, more to the point, how does one makes art resistant to the imposition of an identity in the name of (sometimes myopic) idealism? Rejecting imposed measures and demarcations, Ristićs novel itself_- "bezoblično čudovište za ujed" ("a shapeless monster which bites" or a "shapeless monster to be bitten," both meanings being strategically sustained in this perplexing phrase) (65)-professes to function as a "silent witness" (91) to global injustices. The very duality of the above phrase and one peripheral character may be our best guides to resistant art. In the embedded symbolist play the reader encounters Jan, a character whose brief appearance is vital for the figuration of the novel as a whole. Jan describes his name as being derived from "Ja-Ne," meaning "I-Not I" in Serbo-Croatian, and his very existence as shaped by dialectical tension (185). Formalizing the relationship between the narrator and the protagonist, this character serves as a covert signpost indicating that this anti-novel, out of whose interiority "its very negation erupts" (204), should be understood as a performative of Hegel's philosophy. Ristić, who was simultaneously writing the introductory chapters of his doctoral dissertation in philosophy, studied Hegel avidly during the production of the novel. ${ }^{21}$ Without Measure is peppered with references to Hegel, and its overall composition articulates a passage through the model of thesis, antithesis, and synthesis superimposed on a topography of the author's journey itinerary "PARIS-CANNES-VRNJCI-BELGRADE (March 1927 - May 1928)" (244). ${ }^{22}$ And it is a Hegelian alternative that is invoked explicitly as Ristic denounces imperial labels such as "racial expression" (233) and "Europe in danger." In the dialectical universe of Ristić's Without Measure, it is only to be expected, then, that the first-person narrator's writing also stages a "pamphlet" against its own writer (234), framed as an "I against itself" in the form of Ja-Ne. "This [text] is a pamphlet against myself," he writes, "perpetuated for years, and in vain. This negation would have been creative had it not been tainted by cowardice, compromise, a pleasant smile. I wonder if the crisis-that fundamental crisis which does not obey the measures of utilitarianism, and which is at once the cause and the effect of negation itself-would be enough [to break free]" (234). Permanent 
self-critique, both aesthetic and ethical, was the governing principle of the Belgrade surrealist project, and these words confirm it. But they also offer a more general vision of the self as profoundly dialectical, at once cause and effect, and perpetually split and reshaped in its interaction with the others in the situations of crisis; a self that stares at an execution, executes and is executed; a self that observes the Turkish galley, becomes one with the Turk's melancholy self, and then distances itself to allow the Turk to transform into a Wandering Jew and onward into a Newcastle coal-miner-on a writing pad.

One should take seriously, then, the novel's signature assertion that it is aimed "against the reader" (64), that is, against the passive entity habituated into the logical progression of narrative and history. This proclamation is a call for a more active readerly entity that would be at once the novel's cocreator and its interpreter, thus, an entity that would liberate thought from the prison cell of the previously thought and written. The postulates of Facing a Wall and Bor's photograph series thus also shape Ristićs text. The novel gives varied bodies to the historical subject-in-becoming, but this embodiment is itself subject to provision: Roman/roman is constituted only through the collaboration of the producer and the recipient-interpreter of the text. Hence chapter 14, entitled "Against the Reader," opens with the assertion that the book does not end on its last page. The narrator entreats the reader to abandon "kaišarenje" (64), which translates as both "belt-measure-taking" and "belting." Having read the last word in the novel— "obala," or "shore" (244) — the reader should return to the beginning and continue to read the associative and convoluted foreword that opens the book; and they should feel free to expand their reading down any lines of flight that the text suggests, as this is a book without measures imposed by its author. ${ }^{23}$ The textual monster's existence and shape, indeed its very coming into being, thus depend on our commitment to read against the grain.

Unsurprisingly, then, the text ultimately renounces its prerogatives as a text: it describes itself as an "aktivitet" (47), an "activity," thus a processual entity, a dynamism at the heart of the object. The term aktivitet has limited currency in colloquial Serbo-Croatian; what Ristic likely has in mind here is the specific way in which the term was used in Hegel's Lectures on the History of Philosophy (Vorlesungen über die Geschichte der Philosophie). In response to Aristotle's Nicomachean Ethics, Hegel describes the circumstances governing the abrogation of passivity in the face of thought's propensity for reification. Because thought reifies its own content as being, Hegel reasons, it must be receptive. Dialectically understood, then, the thought-assumed-as- 
object must be simultaneously an instance of active thinking, wherein "der Gegenstand schlägt um in Aktivität" (the object reverses into activity) (Hegel 162). In Ristićs reworking of this insight, a committed readerly pursuit would galvanize this inner capacity of thought to dynamize itself into activity and thus, in turn, cocreate the activity that is the text; this dialectic activity, Ristic believes, is deeply political. Here the producer and user of art become one, enjoined in the aktivitet of endlessly cocreating and co-witnessing historical reality, what Ristić (after Marx) called "umwälzende Praxis," or the reversing, or transforming praxis (Ristić, "Razgovor" 11). The ultimate purpose of such reading-writing activity is, Ristic claims, the "affirmation of the human" (Bez mere 20)—that is, a man's or a woman's realization as a human. Strategically, as we have seen, such realization implies resisting imperial captions.

\section{Coda, or the Merit of Prolepsis}

A remarkable artifact is housed in the boxes containing the Legacy of Marko Ristic at the archive of the Serbian Academy of Sciences and Arts: a small Château de Lancy notebook with the year 1928 handwritten on the cover. ${ }^{24}$ The notebook is filled with Ristić's cultural reflections, quotations, and introspections that led to and followed the publication of Without Measure, all written in blue ink. At one point halfway through the notebook, however, the page is suddenly divided by a thick horizontal line in green ink, under which can be read: "It's May 15, 1943 today, when I'm writing this. The war's ongoing; it's occupation. Here we are in Belgrade . .." (Ristić, Notebook entry). What follows are reflections on bourgeois culture, collaborationism, the North Africa Campaign, imperiality, and meticulous records of everyday life in German-occupied Belgrade. Referring to the surrounding 1928 notes, the writer concludes: "I am still the same person, one who recorded his nausea, his naïve romantic revolt, in this boyish notebook 15 years ago ..."

We have yet to develop a model of thinking that would encompass the past, present, and future lives of modernist objects and their settings. One such model might target the gap staged by the thick green line in Ristićs notebook, taking into consideration, for example, the 1938 publication of Ristićs exceptional long poem Turpituda (Turpitude), almost all 500 first-edition copies of which were confiscated and destroyed, and the very setting of Ristić's 1943 scribbling-his study-salon, dominated by "The Wall of Surrealism," an installation-wall methodically assembled over forty years 
and featuring, among other artifacts, a particularly fine example of Gelẹde headdress from the Yoruba tribe. ${ }^{25}$ Or, better still, I hope for a model that could capture some wider historical ripples relating to the artworks discussed in this essay: the image of a large group of Dorćol Jews walking through the same underpass that Vane Bor memorialized in his photos, herded into their tragic future by German and Belgrade police, in 1941 (another imperial snapshot); tales of the surrealists' arrests, executions, and emigration; Koča Popović's rise through the ranks of military service in the Spanish Republican Forces and Josip Broz Tito's partisans; and the former surrealists' prominent position in the cultural and political landscape of socialist Yugoslavia. It would encompass the future dynamics expanding radially from the surrealist practice: that Ristić, as a member of Société Européenne de Culture, wrote inspiringly on the dignity and service of translators; that Oskar Davičo visited African countries one by one in the 1950s and 1960s and subsequently published a travelogue in which he self-consciously rejects the Orientalizing gaze while suggesting trans-hemispheric solidarity and a commonality of the downtrodden which, he believes, avoids Western imperial and racialized inscriptions; that the ex-surrealists were vitally involved in the 1961 organization of the first Conference of Heads of State or Government of Non-Aligned Countries, an event that occasioned the introduction of night lighting for that inter-imperially charged wall on Kalemegdan Fortress. ${ }^{26}$ (Let it be also said that the non-aligned movement came into being as a supremely inter-imperial creation, forged between and against empires by a cohort of the dissenting-formerly enslaved, colonized, and disenfranchised-but also, paradoxically, as an alternative imperial creation in its own right, inscribed by accreted imperial desires, deep-time projections, and material traces of Egyptian, Persian, Ghana/Wagadou, and Maurya Empires, among others.) Finally, this model would beckon us to notice that the wall in Facing a Wall itself has disintegrated, the area having been bombed by different imperial powers at least three times since the artwork was created, and most recently in 1999.

There are marked gaps between each item on Ristić's "Wall of Surrealism"- gaps which attract us, gaps into which we fall, gaps that provide space for future inscriptions. Ristić's wall is a palimpsest of histories of empires and those who lived among them; but it is also an objet d'art reflecting on its own porosity to our desires and positionalities, our past, present, and future inter-imperial monograms. The above prolepsis indicates just some possibilities opened up by adopting the model of deep and divergent time in a more daring 
fashion-encompassing not only axial points such as the development of nation-states and international capitalism but also multilateral operation of seemingly marginalized agents, and in such a way as to account for both memory and the futurity of art objects. The surrealist artworks I have addressed in this essay are not directly altered by their futures, but they are reconfigured at each historical turn insofar as they are all (meant to be) constituted through interaction between the producer and the receiver. Expanding our inquiries to account for the multiple and ongoing histories of imperial intersection that have inscribed us as both producers and interpreters of artworks can only enrich our understanding of human, lived time. Each cultural artifact we handle is produced by this "lived time": each acts as a writing pad, or a heavily engraved wall, intended for interpretation-even when its inscriptions have been erased by lengthy passages of time and all the more so if its future scribbles are illegible.

\section{Notes}

I would like to acknowledge and thank the following institutions and individuals who made this work possible: Historical Archives of Belgrade; the Archive and Documentation section of the Museum of Contemporary Art, Belgrade; The Legacy of Marko Ristic in the Archive of the Serbian Academy of Sciences and Arts (SASA), Belgrade; the Library Legacy of Marko Ristić in SASA, Belgrade; and Aleksandar Dimitrijević, the author of the photograph of čukur-fountain.

1. On entangled and inter-imperial history of the mesoregion of the Near East and the Balkans/Southeast Europe, see Subrahmanyam (for more on the concepts of connected history and inter-imperiality, especially 1-20); Kaser (for an inter-imperial take on the shared history of the Balkans and the Near East); and Daskalov, Mishkova, Marinov, and Vezenkov (for an overall history of the Balkan region through the lens of entangled history).

2. The Belgrade Surrealist Circle presented their work in various media (painting and print) at the Cvijeta Zuzorić Art Pavilion's annual exhibition salon in October 1932. In the spirit of commitment to conceptual engagement art, they provided information about the Circle's activities while displaying their artwork and, as reports suggest, acting as exhibits themselves. For more on this, see Bahun-Radunović 38.

3. For a more detailed account of the history and dynamics of interaction between the French and the Yugoslav groups, see Bahun-Radunovic, especially 34-48. 
4. For a more detailed discussion of the layout and an alternative discussion of the simulation, see Sretenovic 187-92.

5. For the discussion summarized above, see Popović and Ristic 35-45, and, specifically on the methods of paranoiac simulation, 37-38.

6. On this second operation of the wall in the opus of the Belgrade Surrealist Circle, see Bor and Ristić, especially 47-48 and 53-54. My concept of zero-point of simulation gestures to Roland Barthes's discussion of the zero-degree and neutral writing. For more on this, see Barthes, especially 4-5 and 76-78.

7. On the history of architectural changes in Dorćol, see Norris 72-76.

8. Le Corbusier contextualized these remarks as "youthful" in a later note (39).

9. For a discussion of the Belgrade surrealists' practices, see Levi 46-77. For a discussion of Bor's series of photographs as an articulation of Expressionist cinema, see Todić 35.

10. First Recht and then Benjamin assessed Atget's images of deserted Parisian streets as the scenes of crime, perpetrated in the past or about to be perpetrated. I understand Bor's photographs as operating in exactly the same mode. For these readings, see Recht 15 and Benjamin 256.

11. From 1 to 11 April 1934, workers constructing a twin underpass at this site unearthed the skeletons of soldiers who had unsuccessfully defended Belgrade against the Central Powers in battle on 7 October 1915; Yugoslavia signed a major trade treaty with Germany on 1 May 1934; and King Alexander I was assassinated on 9 October 1934 in Marseilles, France.

12. Herein I correct my erroneous siting in Bahun-Radunović 42.

13. The mystic writing pad, or Wunderblock, is a (toy) note board. It consists of a board covered by a sheet of clear plastic. The user writes on it with any pointed tool, making deep indentations on the board, which appear as dark traces on the plastic sheet. When the plastic sheet is lifted from the surface of the board (or swiped with a tool), the dark traces disappear; indentations beneath, however, may endure. My use of the notion of the writing pad is informed by Sigmund Freud's discussion in "A Note Upon the "Mystic Writing-Pad"” ("Notiz fiber den 'Wunderblock'"), but with an added amount of historical materiality. Freud's text was first published in the Internationale Zeitschrift für Psychoanalyse in 1925, and Ristić likely read it in the original language.

14. All translations from Ristić's novel are mine.

15. Ristić's Without Measure indicates 21 May 1928 as the completion of printing date and Breton's Nadja appeared in print on 25 May 1928. 
16. For the contextualization of this negation in terms of Yugoslav literary history, see Novaković 212-13.

17. Sartre writes: "[T] he aim [of an anti-novel] is to pit the novel against itself, to destroy it under our very eyes (at the same time as it would seem to be erected), to write the novel of a novel that does not, that cannot develop" (7) and thus "safeguard [one's] honesty as a story-teller" (8).

18. Ristić read Joyce and even drafted an essay on Ulysses in 1924 (Ristić, Unpublished draft [fragment]). See Andonovska for more on the surviving fragment of this draft and the comparison between Ristic and Joyce.

19. On this interplay of various types of utterance, textual planes, and elements in Ristić's novel, see Delić 64-66.

20. The information on these periodicals is culled from the contents of Marko Ristićs library, which is housed, as "Library Legacy of Marko Ristic," at the Serbian Academy of Sciences and Arts. On the "imperialism of the spirit," see Martins, especially 1, 7, and 21.

21. Ristić was admitted to doctoral study in philosophy at École normale supérieure, Paris, in 1927, but he abandoned the program in the same year. The surviving drafts of his projected dissertation, La Métaphysique des faits divers (Metaphysics of News), focus on the flaws of traditional metaphysics, the circulation of news, and the category of the dialectic moment; see Ristić, Uoč 243-54.

22. The 1926-27 journey is also recorded in Ristićs simultaneously produced cycle of collages, La vie mobile.

23. The novel opens with a ludic trap for the reader, the citation of the prefatory note in Raymond Roussel's 1897 The Understudy (La Doublure): "as this book is a novel, one must begin on the first page and finish on the last" (Ristić, Bez mere 24). It is precisely this kind of reading that is challenged in Ristić's text.

24. Ristic rescued the notebook from a rat-infested wardrobe. He had likely obtained it as a schoolboy in Switzerland.

25. Inspired by a 1926 visit to Breton's Montmartre flat and produced from 1930 to 1970, this wall, now on permanent display at the Museum of Contemporary Art in Belgrade, is regarded as the first installation in Yugoslav art.

26. For Ristić's thoughts on the dignity and servitude of the translator, see Ristic, "Dignité" 123-24. For Davičo's thoughts on the commonality of the historically marginalized, persecuted, and colonized nations, see Davičo, especially 9 and 20. 


\section{Works Cited}

Andonovska, Biljana. "Ristić i Džojs: Bez mere i Uliks u komparativnoj vizuri" ["Ristić and Joyce: Without Measure and Ulysses in Comparative Perspective"]. Knjižeuna istorija [Literary History] 48.159 (2016): 99-130.

Bahun-Radunović, Sanja. "The Value of the Oblique (Notes on Relational Funhouses, Historical Occlusions, and Serbian Surrealism)." The Avant-Garde and the Margin: New Territories of Modernism. Ed. Sanja Bahun-Radunović and Marinos Pourgouris. Newcastle: Cambridge Scholars, 2006. 26-52.

Barthes, Roland. Writing Degree Zero. Trans. Annette Lavers and Colin Smith. New York: Farrar, 1977.

Benjamin, Walter. "A Small History of Photography." One-way Street and Other Writings. Trans. Edmund Jephcott and Kingsley Shorter. London: New Left, 1979. 240-57

Bor, Vane, and Marko Ristić. Anti-zid: Prilog za pravilnije shvatanje nadrealizma [Anti-wall: A Contribution towards a More Correct Understanding of Surrealism]. Belgrade: Nadrealistička izdanja, 1932.

Davičo, Oskar. Crno na belo [Black on White]. Belgrade: Prosveta, 1962.

De Certeau, Michel. The Practice of Everyday Life. Berkeley: U of California $\mathrm{P}, 1984$.

Dedinac, Milan. Letter to Marko Ristić. 15 Feb. 1927. MS. Legacy of Marko Ristić. Archive of the Serbian Academy of Sciences and Arts, Belgrade.

Daskalov, Roumen, Diana Mishkova, Tchavdar Marinov, and Alexander Vezenkov, eds. Entangled Histories of the Balkans. 4 vols. Leiden: Brill, 2013-2017.

Delić, Jovan. Srpski nadrealizam i roman [Serbian Surrealism and the Novel]. Novi Sad: Srpska književna zadruga, 1980.

Doyle, Laura. "Modernist Studies and Inter-Imperiality in the Longue Durée." The Oxford Handbook of Global Modernisms. Ed. Mark Wollaeger and Matthew Eatough. Oxford: Oxford UP, 2012. 669-96.

Doyle, Laura, and Laura Winkiel. "Introduction: The Global Horizons of Modernism." Geomodernisms: Race, Modernism, Modernity. Ed. Laura Doyle and Laura Winkiel. Bloomington: Indiana UP, 2005. 1-14.

Freud, Sigmund. "Notiz fiber den Wunderblock" ["A Note on the "Mystic Writing-Pad'"]. Internationale Zeitschrift für Psychoanalyse [International Journal of Psychoanalysis] 11 (1925): 1-5.

Grau, Albin. "Vampire." Bühne und Film [Stage and Film] 21 (1921): 6-7.

Hegel, G. W. F. "Metaphysik" ["Metaphysics"]. Vorlesungen über die Geschichte der Philosophie II [Lectures on the History of Philosophy II]. Vol. 19. Ed. Eva Moldenhauer and Karl Markus Michel. Berlin: Suhrkamp, 1986. 151-67.

Kaser, Karl. The Balkans and the Near East: Introduction to a Shared History. Münster: LIT Verlag, 2011.

Le Corbusier. Journey to the East. Ed. Ivan Žaknić. Trans. Žaknić, John Gery, and Nicole Pertuiset. Cambridge: MIT P, 1989. 
Levi, Pavle. Cinema by Other Means. Oxford: Oxford UP, 2012.

Martins, Catarina. "Imperialism of the Spirit: Fictions of Totality and the Self in Austrian Modernism." Revista Crítica de Ciências Sociais [Critical Journal of Social Sciences] 1.1 (2009): 1-21.

Norris, David A. Belgrade: A Cultural History. Oxford: Oxford UP, 2009.

Novaković, Jelena. Na rubu halucinacija: poetika srpskog i francuskog nadrealizma [At the Verge of Hallucinations: Poetics of Serbian and French Surrealism]. Belgrade: Filološki fakultet, 1996.

O’Dawd, Liam. "Contested States, Frontiers, and Cities." A Companion to Border Studies. Ed. Thomas M. Wilson and Hastings Donnan. Hoboken: Wiley-Blackwell, 2012. 158-76.

Popović, Koča, and Marko Ristić. Nacrt za jednu fenomenologiju iracionalnog [Outline for a Phenomenology of the Irrational]. Belgrade: Prosveta, 1985.

Recht, Camille. Introduction. Lichtbilder. By Eugène Atget. Leipzig: Verlag Henri Jonquières, 1930. 5-28.

Ristić, Marko. Bez mere [Without Measure]. Belgrade: Nolit, 1986. . "Dignité et Servitude du Traducteur" ["On the Dignity and Servitude of the Translator"]. Babel 9.3 (1963): 123-24.

- Notebook entry. 15 May 1943. MS. Legacy of Marko Ristić. Archive of the Serbian Academy of Sciences and Arts, Belgrade.

. Oko nadrealizma I [Around Surrealism]. Belgrade: Clio, 2003.

. "Pred jednim zidom—objasnjenje istoimene strane ilustracija" ["Facing a Wall-An Explanation of the Eponymous Illustration Page"]. Nadrealizam danas $i$ ovde [Surrealism Today and Here] 3 (1932): 51.

. "Razgovor sa Markom Ristićem: Ništa nije bilo uzalud" ["Conversation with Marko Ristić: Nothing Has Been In Vain"]. By Milan Mirić. Telegram 21 Nov. 1969: 11-14.

- Unpublished draft [fragment]. MS. Legacy of Marko Ristić. Archive of the Serbian Academy of Sciences and Arts, Belgrade.

- Uoči nadrealizma [At the Onset of Surrealism]. Belgrade: Nolit, 1985.

Sartre, Jean-Paul. Preface. Portrait d'un inconnu [Portrait of a Man Unknown]. By Nathalie Sarraute. Paris: Robert Marin, 1948. 7-14.

Sretenović, Dejan. Urnebesni kliker: umetnost i politika beogradskog nadrealizma [The Frenzied Marble: Art and Politics of the Belgrade Surrealist Circle]. Belgrade: Službeni glasnik, 2016.

Subrahmanyam, Sanjay. Explorations in Connected History: Mughals and Franks. Oxford: Oxford UP, 2005.

Todić, Milanka. "Izvan utvr enih granica: fotografski ekperimenti Vaneta Živadinovića Bora" [ "Beyond Fixed Borders: Vane Živadinović Bor's Experiments in Photography”]. Iznadrealizma [Overfromsurrealism]. Ed. Goran Milenković and Violeta Stojmenović. Bor: Narodna biblioteka Bor, 2008, pp. 24-40.

Todorova, Maria. "Spacing Europe: What is a Historical Region?" East Central Europe 32. 1/2 (2005): 59-78.

Yovitchitch [Jovičić], A. Lena. Peeps at Many Lands: Yugoslavia. London: A. \& C. Black, 1928. 